\title{
Vincze Attila[1]: Nótári Tamás: Studia Iuridico-philologica I. Nótári Tamás: Studia Iuridico-philologica I. Studies in Classical and Medieval Philology and Legal History. Hungarian Polis Studies 14. Debrecen 2007. 313 oldal
}

\author{
Debreceni Jogi Mühely, 2009. évi (VI. évfolyam) 2. szám (2009. április)
}

Németh György professzor szerkesztésében megjelenő Hungarian Polis Studies sorozat 14. köteteként jelent meg 2007-ben Nótári Tamás, a Károli Gáspár Református Egyetem docensének, idegen nyelvü tanulmánygyüjteménye, mely angol, német valamint francia nyelven csokorba gyüjtött válogatását adja a szerző elmúlt években magyarul már olvasható tanulmányainak. Az ókor és (kora) középkor világába betekintést engedő írások ugyanakkor nem puszta fordításai a korábbi publikációknak, ezeket a szerző ugyanis mind tartalmukban, mind a citált szakirodalmat tekintve bővítette és kiegészítette. A kronologikus sorrendet követö „Studia Iuridico-philologica I. Studies in Classical and Medieval Philology and Legal History" című jog- és kultúrtörténeti kötet az olvasó számára a görög és a római jog- és vallástörténet valamint filológia, illetve a bajor historiográfia egyes jogtörténetileg érdekes kérdését villantja fel. Már előjáróban érdemes kiemelni a kötet gazdag jegyzetapparátusát, a szerkesztés precizitását, az igényes tipográfiát és esztétikus küllemét, melyek csak emelik az amúgy is értékes belbecs értékét.

Görög jogtörténet és jogbölcselet területe két írással képviselteti magát.[2] Az első (The Scales as the Symbol of Justice in the Iliad) a mérleggel, mint az igazságosság jelképével foglalkozik. Iustitia ábrázolásának - kis túlzással - „kötelező eleme” a kezében tartott mérleg, mellyel mint az igazság(osság), az igazságszolgáltatás eszközével és jelképével a görög irodalomban több helyen is találkozhatunk. Nótári azt szöveghelyet elemzi az Iliászból behatóbban, amelyben Zeusz a mérleg segítségével ítéletet mond a hősök felett. Az írás az igazság mérlege kifejezést vizsgálva a jognak, illetve az igazság(osság)nak Homérosznál kifejlődött fogalmát tisztázza, illetve az eposz mérési jelenetét elemezve boncolja a mérlegszimbolika eredetét, jelentését, és feltünését a különböző kultúrákban, így az egyiptomiban, a görögben és a rómaiban.[3] A második görög témájú írás (Hesiod und die Anfänge der Rechtsphilosophie) a Kr. e. VIII. és VII. század fordulóján élt Hésiodos művei alapján igyekszik az antik jogfilozófia kezdeteit felvillantani. A Munkák és napok (Erga kai hémerai), mint tanköltemény, didaktikus eposz, tanköltemény, célja az, hogy Hésiodos az ellene oly sok igazságtalanságot elkövető testvérét, Persést a munka és a jog tiszteletére tanítsa. Nótári ebben a tanulmányában a görög jogfillozófia vizsgálata során gyakran és méltatlanul mellözött münek a jogról és a jogérvényesítésről kialakított koncepcióját elemzi. A szerző az emberi munka, illetve a jogrendszer szükségességének költői indokolását vizsgálja, illetve a diké fogalmának előfordulását és szerepét a homérosi eposzokban és a hésiodosi müben.[4]

A latin filológiába illetve a római jog- és vallástörténet egy-egy aspektusát öt tanulmány elemzi.[5] A Numen and Numinousity - On Some Aspects of the Roman Concept of Authority címü írás a tekintély római fogalmát igyekszik az olvasó elé tárni. A szerző találóan idézi Hannah Arendtet aki szerint a rómaiak alapvetően „szinte azonosnak tekintették a vallási és a politikai tevékenységet".[6] E gondolatra felfüzve kerül meghatározásra az auctoritas, mint a növelés, a gyarapítás képességének vallási-filozófiai definíciója, amit követ a numen mint a római vallás igen sarkalatos jelenségének különféle aspektusainak illetve etimológiájának vizsgálata, két, e szempontból relevánsnak tünő jelenség a triumphus intézménye és a flamen Dialis funkciója[7] illetve Augustus ideológiai koncepciója bemutatásával .[8] 
A jogértelmezési maximákról a szerző a közelmúltban, az elmúlt hosszú évtizedek magyar jogtudományában egyedülállóan, latin nyelvü tanulmányt is publikált.[9] A tanulmány bemutatja az interpretatio kifejezés kialakulását és jelentését, valamint igen tág teret szentel a summum ius elv jelentésének az ars boni et aequi fogalmának tükrében. A szerző ismerteti a nevezetes ciceroi szöveghelyet: „Existunt saepe iniuriae calumnia quadam et nimis callida, sed malitiosa iuris interpretatione. Ex quis illud 'summum ius summa iniuria' factum est iam tritum sermone proverbium.”[10] Cicero gondolatmenetében - ahogy az az idézetből is kitünik - nem a jogi és morális (ius és mos) normák ütköznek, hanem a kollízió a jogrenden belül következik be, azaz azon elvárás fogalmazódik meg, hogy a jogot helyesen és igazságosan kell alkalmazni.[11]

A legis actiós eljárással történetiségével két tanulmány is foglalkozik: Die Lanze als Machtund Eigentumssymbol im antiken Rom[12]; Remarks on the Origin of the legis actio sacramento in rem.[13] A legis actio sacramento in rem leírásában Gaius elbeszéli, hogy az eljárás során a pálcát mintegy a lándzsa helyett használták a jogszerű tulajdon jeleként, Verrius Festus szerint pedig a lándzsa a legfőbb hatalom jelképe. E két forrásból kiindulva vizsgálja a szerző a lándzsa és a pálca hatalmi jelképiségét, számos jog- és vallástörténeti párhuzam, illetve analógia segítségével, értékes következtetéseket von le a ius fetiale és a legis actio sacramento in rem közös elemeit, gyökereit illetően.[14] Remarques sur le ius vitae necisque et le ius exponendi.[15] A pater familiast személyileg megillette a ius vitae ac necis, ius exponendi, ius vendendi, ius noxae dedendi, ahogy azt minden joghallgatónak tanulmányai első félévében meg kell tanulnia. A tanulmány a ius vitae ac necis és a ius exponendi alakulását vesszük behatóbb elemzés alá. A ius vitae ac necis a családgyermek élete és halála felöli rendelkezési jogot jelöli, míg a ius exponendi az újszülött gyermek kitevésének jogát. A gyermek kitétele gyakran annak halálát, illetve szándékos megölését is magában foglalta, így például a torzszülött gyermek esetén, amikor a cél a családnak, illetve a közösségnek a szerencsétlenséget jelentő prodigiumtól való megszabadítása volt.[16]

A kora középkori bajor historiográfiával és jogtörténettel foglalkozó rész[17] Virgil, Salzburg ír származású püspöke (749-784) tevékenységének elemzésével kezdődik. Nevéhez füződik a salzburgi historiográfia legkorábbi műveinek, a Gesta sancti Hrodberti confessoris, a Libellus Virgilii és a Liber confraternitatum megalkotása, a 774-ben felszentelt Rupert-dóm megépíttetése, a püspökség és a Szent Péter-kolostor jogainak kiterjesztése és a karantánok közti misszió megszervezése. A korszak bajor bel- és külpolitikai viszonyaink elemzésé követően tér rá a szerző Virgil és Bonifác összeütközésének bemutatására. Az Aethicus Ister nevéhez füződő, Cosmographia címet viselő munka kapcsán kimutatja, hogy a szerzőként vélelmezett Virgilnek Bonifáccal lezajlott konfliktusának nyomait a müben, majd behatóan górcső alá veszi Virgil bajorországi működését, kitérve a Libellus Virgiliiben leírt birtokviták jogi hátterére is.[18]

III. Tasziló trónfosztásának bemutatása során a szerző először a bajor herceg hűségesküit veszi sorra, majd magát a koncepciós pert, végül pedig annak jogi hátterét és indokolását elemzi. III. Taszilót, a Bajorországban két évszázadon át uralkodó Agilolfing-dinasztia utolsó hercegét trónjától Nagy Károly fosztotta meg. A frank uralkodó előbb mind kül-, mind pedig belpolitikailag elszigetelte Taszilót, majd 787-ben vazallusává tette. Fő vádként a hủbérúr iránti hütlenséget, valamint a királyi sereg engedély nélküli elhagyását hozták fel Tasziló ellen - igaz, az utóbbi cselekményre negyed századdal a per előtt került sor.[19]

A Metóddal foglalkozó írásban a szerző a bemutatja a missziós tevékenységet, majd a történeti háttér feltárása után Metód regensburgi perének körülményei felé fordítja figyelmét a Conversióban megfogalmazott vádakra, illetve ezek hátterére, valamint Metód tanításának további sorsára világít rá a jogtörténész-medievista szemszögéből.[20]

Ingo története Enea Silvio Piccolomini 1458-ban írt De Europa címü müvének Karintiával foglalkozó huszadik könyve hatvanötödik fejezetében kerül elő. A történet müfajilag 
legendaként sorolható be, mely egy Ingo nevü, Nagy Károly idejében élt hercegről szóló történetet beszél el. A szerző több kérdésre keres választ ebben az írásban. Mennyiben tekinthető az Enea Silvio által említett és hosszú évszázadokon át a szakirodalomban meg nem kérdőjelezett Ingo herceg valós történelmi személynek? A Conversio valóban hercegként említi-e Ingót, és ha nem, akkor minek köszönheti hercegi létét, illetve hercegkénti bevonulását az irodalomba? A Conversio által említett carta sine litteris mit jelenthetett, és miért nem vette át Enea Silvio e mozzanatot is, noha Ingo tekintélyének további bizonyítékául hozhatta volna fel? Az Ingo-féle lakoma leírása milyen irodalmi elözményekre vezethető vissza, és milyen szerepet töltött be a Conversióban?[21]

A kötet lezárásaként[22] a szerző mestereinek, a nemzetközi hírü klasszika-filológus és bizantinológus Szádeczky-Kardoss Samunak és a középkorász, Kristó Gyulának állít emléket, és ad életmüvükről tudománytörténetileg értékes portrét.[23]

[1] Egyetemi tanársegéd, ELTE ÁJK, Alkotmányjogi Tanszék

[2] The Scales as the Symbol of Justice in the Iliad. i.m. 9-20; Hesiod und die Anfänge der Rechtsphilosophie. i.m. 21-44.

[3] Vö. Nótári T.: A mérleg mint az igazságszolgáltatás jelképe Homérosnál. Collega 2002/2. 43. skk.; Vallástörténeti megjegyzések az Aeneis XII. 725-727. sorához. Belvedere Meridionale 1999/5-6. 4. skk.; The Scales as the Symbol of Justice in the Iliad. Acta Juridica Hungarica 2006. 249. skk.; Iuridicophilologica - Tíz tanulmány. Budapest 2004. 9. skk.

[4] Vö. Nótári T.: Hésiodos jogkoncepciója. Jogtudományi Közlöny 2005 328. skk.; Hamza G.-Nótári T.: Mit hoz a múlt? Jog- és kultúrtörténeti tanulmányok I. Budapest, 2006. 25. skk.; Bürgergemeinschaft und Rechtsgedanke bei Hesiod. In: Politai et Cives. Epigraphica III. Hungarian Polis Studies 13. Ed. György Németh-Péter Forisek. Debrecen 2006. 7. skk.; Hesiod und die Anfänge der Rechtsphilosophie. Annales Universitatis Scientiarum Budapestinensis de Rolando Eötvös nominatae, Sectio Iuridica 47. 2006. 341. skk.; Iuridicophilologica - Tíz tanulmány. Budapest 2004. 19. skk.

[5] Numen and Numinousity - On Some Aspects of the Roman Concept of Authority. i.m. 45-74; Summum ius summa iniuria - The Historical Background of a Legal Maxim. i.m. 7596; Die Lanze als Macht- und Eigentumssymbol im antiken Rom. i.m. 97-128; Remarks on the Origin of the legis actio sacramento in rem. i.m. 129-152; Remarques sur le ius vitae necisque et le ius exponendi. i.m. 153-178.

[6] Vö. Hannah Arendt, H.: Mi a tekintély? In: Múlt és jövő között. Budapest 1995. 130.

[7] Nótári, T.: The Function of the Flamen Dialis in the Marriage Ceremony. Annales Universitatis Scientiarum Budapestinensis de Rolando Eötvös nominatae, Sectio Iuridica 2004. 157. skk.; De matrimonio cum manu in iure sacro civilique. In: Cultus deorum. Studia religionum ad historiam II. De rebus aetatis Graecorum et Romanorum. In memoriam István Tóth. (Ókortudományi Dolgozatok 2. Szerk. Szabó Á.-Vargyas P.) Pécs 2008. 93. skk.; De duabus caeremoniis iuris antiqui in Ciceronis oratione pro Murena. Vox Latina 45. 2009. 2. skk.

[8] Vö. Nótári T.: On Some Aspects of the Roman Concept of Authority. Acta Juridica Hungarica 2005/1-2. 95. skk.; Iuridicophilologica - Tíz tanulmány. Budapest 2004. 141. skk.; Numen és numinozitás - a római tekintély fogalom vallási gyökerei. Aetas 2003/4. 33. skk.; Hogyan nyerjük meg a választásokat? Quintus Tullius Cicero: A hivatalra pályázók kézikönyve. Fordította, a jegyzeteket, az előszót és az utótanulmányt írta Nótári T. Szerkesztette és a kísérő tanulmányt írta Németh Gy. Szeged 2006. 33. skk. 
[9] Nótári, T.: De summo iure summaque iniuria apud Ciceronem. Vox Latina 43. 2007. 346. skk.

[10] Cicero, De officiis 1, 33.

[11] Vö. Nótári, T.: Summum Ius Summa Iniuria - Comments on the Historical Background of a Legal Maxim of Interpretation. Acta Juridica Hungarica 44, 2004/1-2. 301. skk.; Summum ius summa iniuria. Magyar Jog 2004. 7. 385. skk.; Megjegyzések egy jogértelmezési maxima történeti hátteréhez. Jogtudományi Közlöny 59. 2004/7-8. 221. skk.; Iuridicophilologica - Tíz tanulmány. Budapest 2004. 93. skk.

[12] Nótári i.m. 97-128.

[13] Nótári i.m. 129-152.

[14] Nótári T.: Jog, vallás és retorika. Szeged 2006. 50. skk.; Duellum sacrum - gondolatok a legis actio sacramento in rem eredete kapcsán. Állam- és Jogtudomány 2006/1. 87. skk.; Adalékok a legis actio sacramento in rem eredetéhez. Antik Tanulmányok 2007. 71. skk.; Comments on the Origin of the legis actio sacramento in rem. Acta Juridica Hungarica 2006/2. 133. skk.; Festuca autem utebantur quasi hastae loco. Acta Facultatis PoliticoIuridicae Universitatis Budapestiensis de Rolando Eotvos nominatae 2004. 133. skk.; The Spear as the Symbol of Property and Power in Ancient Rome. Acta Juridica Hungarica 48. 2007/3. 231. skk.; Die Lanzensymbolik der legis actio sacramento in rem. Studia Iuris Caroliensia 2. 2007. 135. skk.

[15] Nótári i.m. 153-178.

[16] Nótári T.: De iure vitae necisque et exponendi. Jogtudományi Közlöny 53. 1998/11. 421. skk.; Remarques sur le ius vitae necisque et le ius exponendi. Studia Iuris Caroliensia 1. 2006. 151. skk.; A gyermek megölésének joga az ókori Rómában. Jogelméleti Szemle 2007/3; A gyermekkitevés joga az ókori Rómában. Jogelméleti Szemle 2004/2.

[17] Comments on Bishop Virgil's Activity in Bavaria. i.m. 179-202; Tasilo III's Dethronement - Remarks on an Early-Medieval Show Trial. i.m. 203-232; The Trial of Methodius in the Mirror of the Conversio Bagoariorum et Carantanorum. i.m. 233-282; Die Geschichte des Ingo bei Enea Silvio Piccolomini. i.m. 283-304.

[18] A kora középkori bajor történelemhez lásd Nótári T.: A salzburgi historiográfia kezdetei. Szegedi Középkortörténeti Könyvtár 23. Szeged 2007; Források Salzburg kora középkori történetéből. Szeged 2005; Adalékok Virgil apát és püspök bajorországi müködéséhez. In: Medievisztikai tanulmányok, Szeged 2005 99. skk.; Két forrás a kora középkori Salzburgból, Notitia Arnonis - Epistola Theotmari. Aetas 2004/2. 72. skk.; Salzburg neve a kora középkori forrásokban. Collega. 2005/1. 48; Az univerzum képe Aethicus Ister Cosmographiájában. Belvedere Meridionale 2005. 5-6. 38. skk.; Gesta Hrodberti. In: Classica - Mediaevalia Neolatina. Edd. L. Havas et E. Tegyey. Debrecen 2006. 131. skk.; Virgil és Bonifác - egy konfliktus jogi és irodalmi síkjai a kora középkorban. Jogtudományi Közlöny 2007. 3. 100. skk.; Virgil püspök bajorországi jogvitáinak margójára. In: Tanulmányok Máthé Gábor 65. születésnapja tiszteletére. Szerk. Mezey B.-Révész T. M. Budapest 2006. 369. skk.; On Bishop Virgil's Litigations in Bavaria. Acta Juridica Hungarica 2007. 1. 49. skk.

[19] Vö. Nótári T.: III. Tasziló trónfosztása - adalék egy koraközépkori koncepciós perhez. Jogtudományi Közlöny 2005. 503. skk.; Tassilo III's dethronement - contributions to an early-middle-age show trial. Publicationes Universitatis Miskolciensis. Sectio Iuridica et Politica 2005. 65. skk.; Személyállapot és társadalomszerkezet a kora középkori Bajorországban. Acta Facultatis Politico-Iuridicae Universitatis Budapestinensis 42. 2005. 163. skk.; III. Leó pere és az Salzburgi Érsekség megalapítása. Collega 2005/4. 55. skk.; A kora középkori salzburgi birtokjegyzékek margójára. Jogelméleti Szemle 2006/3.; Egy kora középkori koncepciós per - III. Tasziló trónfosztása. In: Hamza G.-Nótári T.: Mit hoz a múlt? Jog- és kultúrtörténeti tanulmányok I. Budapest, 2006. 261. skk. 
[20] A Conversióhoz lásd Nótári T.: Conversio Bagoariorum et Carantanorum. Aetas 2000/3. 93. skk.; Avarok a Kárpát-medencében - Szádeczky-Kardoss Samu: Az avar történelem forrásai. Belvedere Meridionale 12. 2000/3-4. 110. skk.; Megjegyzések a Conversio Bagoariorum et Carantanorum avar vonatkozású fejezeteihez. In: Tanulmányok a középkorról. A II. Medievisztikai PhD-konferencia előadásai. Szeged 2001. 67. skk.; De Consultis Bulgarorum. Collega 2002/5. 47. skk.; Róma és Bizánc missziós kísérletei a IX. századi Bulgáriában. Belvedere Meridionale 2005/1-2. 22. skk.; A Salzburgi Érsekség és Metód konfliktusa a Conversio Bagoariorum et Carantanorum tükrében. Belvedere Meridionale 2005. 3-4. 37. skk.; On the Avar-related chapters of the Conversio Bagoariorum et Carantanorum. Chronica 2005. 26. skk.; Conversio Bagoariorum et Carantanorum Document of an Early Medieval Show Trial. Publicationes Universitatis Miskolciensis. Sectio Iuridica et Politica 25. 2007. 95. skk.

[21] Ehhez lásd Nótári T.: Szemelvények Aeneas Sylvius Piccolomini „Európa” c. müvéből fordítás és bevezetés. Documenta Historica 42. A JATE Történész Diákkör kiadványa. Szeged 1999; Timur Lenk és I. Bajazid Aeneas Sylvius Piccolomini „Európa” című művében. Belvedere Meridionale 11. 1999/5-6. 89. skk.; A török terjeszkedés állomásai Aeneas Sylvius Piccolomini „Európa” című művében. Aetas 1999/4. 149. skk.; Aeneas Sylvius Piccolomini szónoki müvészete. Középkortörténeti tanulmányok, A III. Medievisztikai PhD-Konferencia előadásai. Szerk. Weisz B. Szeged 2003. 103. skk.

[22] Portrait zweier ungarischer Mediävisten, Gyula Kristó und Samu Szádeczky Kardoss. i.m. 305-313.

[23] Vö. Nótári T.: Emlékezés Szádeczky-Kardoss Samu professzora. Jogtörténeti Szemle 2005. 1. 44. skk.; In memoriam Samuelis Szádeczky-Kardoss piissimam. Vox Latina 2005. 142. sk.; En memoire de Professeur Samuel Szádeczky-Kardoss. Acta Antiqua 46. 2006/3. 209. skk.; Szádeczky-Kardoss Samu (1918-2004). Aetas 2005. 4. 182. skk.; In memoriam Kristó Gyula. Jogtörténeti Szemle 2004/2. 63. sk. 